\title{
PENERAPAN PAKAN SUPLEMEN BLOK UKKMB DAN JERAMI FERMENTASI PADA PKM KELOMPOK TANI TERNAK SAPI BALI DI DESA LEMPANG KECAMATAN TANETE RIAJA KABUPATEN BARRU
}

\author{
Effendi Abustam, Muhammad Yusuf, dan Muhammad Irfan Said \\ E-mail: effendiabu@hotmail.com
}

\begin{abstract}
PKM Livestock Farmers Group in Lempang Village Barru District has been conducted on two partners namely Sikapa Livestock Group and Livestock Group Padaelo in Tanete Riaja District which lasts from July to September 2018. The technology applied by the team is the manufacture of UKKMB blocks feed supplement and probiotic fermentation straw on. This activity aims to improve the skills of members of livestock groups in the application of livestock technology, especially in the manufacture of feed. The productivity of Bali cattle needs to be improved through the provision of quality feed as one of the problems found. The implementation method is in the form of training (theory and practicum), action review, mentoring and application of feed products to Bali cattle in a cage. Making modified feed supplements in the form of UMMB into Urea Water Collagen Coconut Multinutrient Block (UKKMB) and probiotic fermented rice straw is the main product tried in Bali cattle at home. The provision of block supplement feed in Bali cattle increases appetite and feed consumption. The results of the activity showed that UKKMB and probiotic fermented rice straw could solve the problem of the availability of feed in the cage and the increase in cattle weight.
\end{abstract}

Keywords: body weight, fermented straw, livestock group, Bali cattle, UKKMB

\section{PENDAHULUAN}

Pengandangan ternak sapi Bali merupakan upaya untuk meningkatkan kinerja sapi tersebut melalui introduksi teknologi yang lebih mudah diberikan pada sistem pemeliharaan tersebut. Sekalipun diketahui bahwa sapi Bali mampu beradaptasi dengan baik pada lingkungan yang kurang baik dengan kualitas pakan yang rendah (Sastradipradja, 1990). Keunggulan lain sapi Bali adalah persentase karkas dapat mencapai 52-57.7\% dengan kadar lemak daging rendah yakni kurang lebih 4\% (Payne dan Hodges, 1997). Pada pemeliharaan tradisional di Sulawesi Selatan kadar lemak daging sapi Bali dibawah 2\% (Abustam, 1993). Pengandangan ternak sapi Bali menimbulkan problem dalam pemberian pakan secara cut and carry; membutuhkan waktu untuk memotong rumput dan memberikan kepada sapi di kandang. Dimana pada musim kemarau menjadi lebih berat lagi karena ketersediaan rumput yang semakin berkurang.

Kecamatan Tanete Riaja sebagai wilayah dengan populasi Sapi Bali yang menempati urutan kedua tertinggi (11.664 ekor pada tahun 2012) di Kabupaten Barru (BPS, 2013), telah melaksanakan pengandangan ternak dengan istilah showroom. Peternak secara berkelompok melakukan usaha pengembang biakan dan penggemukan Sapi Bali.

Permasalahan utama yang dikemukakan oleh mitra PKM, secara umum dapat disimpulkan adalah penyediaan pakan. Konsekuensi dari pengandangan ternak mengharuskan para peternak untuk memberikan pakan hijauan secara cut and carry, memotong rumput gajah atau jerami lalu diberikan ke ternak sapi di kandang.

Penerapan teknologi fermentasi jerami probiotik dan pemberian pakan suplemen dalam bentuk Urea Air Kelapa Kolagen Multi Nutrient Blok (UKKMB) merupakan salah satu solusi yang dapat memecahkan ketersediaan pakan. UKKMB merupakan modifikasi UMMB dimana molases diganti dengan air kelapa (Abustam dkk, 2015) dan ditambahkan kolagen hidrasi sebagai pengawet dan antioksidan. Hasil penelitian sebelumnya memperlihatkan bahwa semakin meningkat persentase kolagen dalam pakan UKKAMB kualitas daging sapi Bali semakin meningkat (Abustam dkk, 2017).

Kegiatan ini bertujuan untuk mendapatkan pakan suplemen blok dan jerami padi fermentasi yang dapat memenuhi kebutuhan sapi Bali di kandang.

\section{PENDEKATAN/METODA YANG DIGUNAKAN}

Penerapan Ilmu Pengetahuan dan Teknologi pada masyarakat dalam hal ini kelompok tani ternak sebagai mitra PKM dilakukan pada Kelompok Tani Ternak Sikapa dan Padaelo melalui pendekatan pelatihan (teori dan praktikum), kaji tindak, pendampingan dan penerapan produk pakan pada sapi Bali di kandang. 


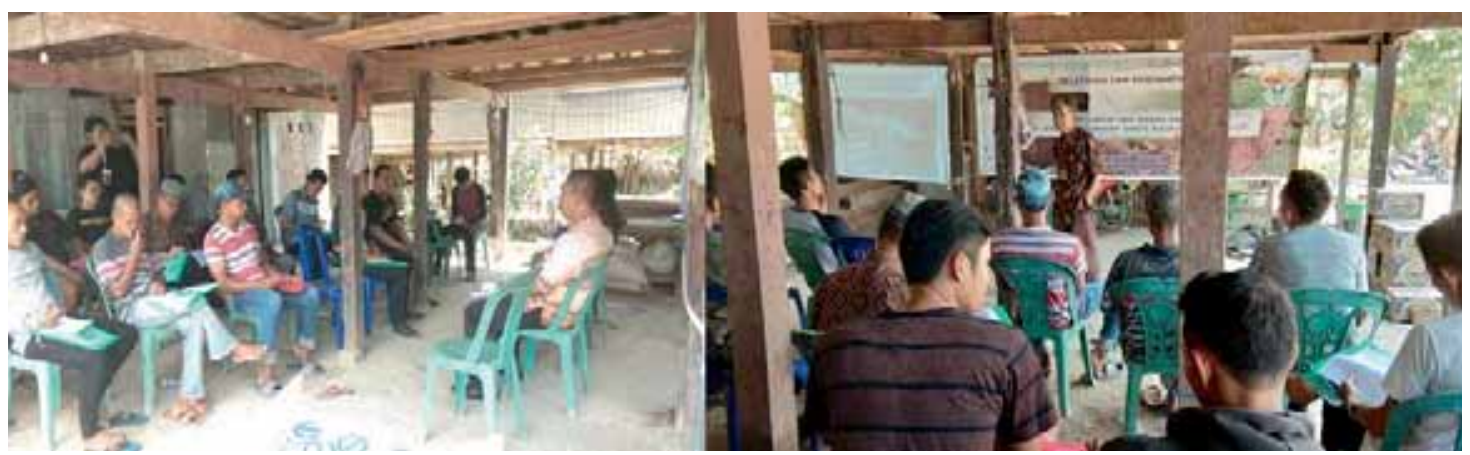

Gambar 1. Acara pembukaan dan pemaparan materi teknologi pembuatan pakan suplemen blok UKKMB dan jerami padi fermentasi probiotic

\section{Pelatihan (Teori dan Praktikum)}

Pelatihan dirancang sedemikian rupa sehingga input teknologi yang diberikan dapat diterima dengan cepat oleh para anggota kedua kelompok ternak. Untuk itu materi disajikan langsung menyangkut Teknologi Pembuatan Pakan UKKMB dan Teknik Pembuatan Pakan Jerami Fermentasi. Setelah penyajian materi dilanjutkan dengan praktek langsung terhadap materi yang telah disajikan.

\section{Pendampingan}

Keberlanjutan pemberdayaan anggota kedua kelompok ternak sebagai mitra PKM (Sikapa dan Padaelo) agar dapat berkelanjutan maka pendampingan dilakukan baik dalam proses produksi maupun dalam pemasaran.

\section{Penerapan Produk Pakan}

Produk pakan dalam bentuk jerami padi fermentasi probiotik dan pakan suplemen blok UKKMB yang dihasilkan oleh mitra PKM kemudian diberikan kepada ternak sapi Bali di kandang. Pengukuran berat badan dilakukan untuk mengetahui pertambahan bobot badan per hari selama pemberian pakan. Jumlah pakan yang diberikan dibatasi sebanyak $6 \mathrm{~kg}$ jerami padi fermentasi probiotik dan 500gr UKKMB per hari.

\section{PEMBAHASAN}

Acara pelatihan diawali pembukaan yang dibuka oleh Peternakan Kecamatan Tanete Riaja Bapak Hasrun. Setelah pembukaan dilanjutkan pemaparan materi. Gambar 1 dan 2 memperlihatkan suasana pembukaan pelatihan.

Peserta pelatihan sebanyak 30 orang dengan antusias mengikuti pemaparan materi pelatihan yang disajikan. Pada Gambar 3 terlihat praktikum pembuatan pakan UKKMB oleh peserta pelatihan.

\section{Urea Air Kelapa Kolagen Multi Nutrien Blok (UKKMB)}

Setelah pemaparan materi dilanjutkan dengan praktikum pembuatan pakan suplemen urea air kelapa kolagen multinutrien blok (UKKMB). Ada 3 macam UKKMB yang berbeda persentase kolagen dalam formulasi pakan suplemen blok yakni 100\%, 50\%, dan 25\% (rasio air: kolagen; 1:1, $1: 2$, dan 1:4) dengan tingkat pemberian $2 \%$ dalam formulasi. Komposisi bahan pakan suplemen blok dapat dilihat pada Tabel 1.

Tabel 1. Komposisi bahan pakan dalam UKKMB

\begin{tabular}{lccc}
\hline \multirow{2}{*}{ Bahan Pakan } & \multicolumn{3}{c}{ Komposisi (\%) Pada Konsentrasi Kolagen } \\
\cline { 2 - 4 } & $\mathbf{2 5 \%}$ & $\mathbf{5 0 \%}$ & $\mathbf{1 0 0 \%}$ \\
\hline 1. Air kelapa & 28 & 28 & 28 \\
2. Urea & 5 & 5 & 5 \\
3. Dedak padi & 30 & 30 & 30 \\
4. Jagung halus & 10 & 10 & 10 \\
5. Bungkil kelapa giling & 10 & 10 & 10 \\
6. Semen & 10 & 10 & 10 \\
7. Mineral sapi & 2 & 2 & 2 \\
8. Garam dapur & 3 & 3 & 2 \\
9. Kolagen Hidrasi & 2 & 2 & 2 \\
\hline
\end{tabular}




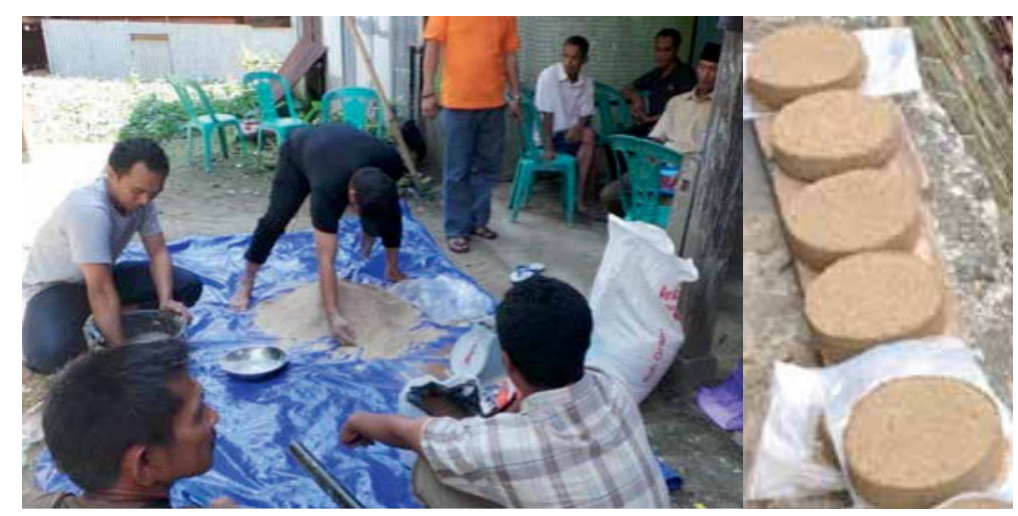

Gambar 2. Praktikum pembuatan pakan suplemen UKKMB

Pada gambar 2 terlihat peserta pelatihan melakukan pembuatan pakan UKKMB dengan antusias. Pascapelatihan mitra PKM telah melaksanakan pembuatan pakan UKKMB sejumlah $50 \mathrm{~kg}$ yang diperuntukkan sebagai pakan sapi Bali yang dijadikan sebagai materi percobaan untuk melihat pertambahan bobot badan.

Produk UKKMB merupakan produk modifikasi dari Urea Molases Mineral Blok (UMMB) dimana molasses yang kadang kala sulit diperoleh dan harga mahal digantikan dengan air kelapa segar yang mudah diperoleh dengan harga sangat murah. Pada formulasi pakan UKKMB ditambahkan kolagen sebagai antioksidan dan bahan pengawet (Abustam dkk, 2015). Jika dibandingkan dengan UMMB dimana kadar protein, serat kasar, dan abu yang lebih rendah sementara kadar lemak dan BETN lebih tinggi (Abustam dkk, 2012; 2015). Kadar protein, lemak, dan serat kasar yang tinggi pada UKKMB dapat dipertimbangkan sebagai pakan suplemen yang dapat memenuhi kebutuhan zat-zat nutrient pada sapi Bali. Pada Tabel 2 terlihat kadar protein dan lemak yang tinggi pada UKKMB hidrasi kolagen 1:2 (25\% kolagen), sementara kadar serat kasar lebih tinggi dan kadar abu lebih rendah dibanding dengan UKKMB 50\% dan UKKMB 100\% (Tabel 2).

Hasil analisis kadar nutrisi UKKMB terlihat pada tabel 2. Kadar protein rata-rata dari ketiga persentase kolagen yang ditambahkan ke dalam pakan suplemen blok yakni $23.59 \%$ dimana tertinggi pada UKKMB 25\% yakni $25.06 \%$ akan mampu untuk memenuhi kebutuhan protein bagi sapi

Tabel 2 Kadar nutrisi (\%) produk pakan UKKMB

\begin{tabular}{|c|c|c|c|c|c|c|c|}
\hline \multirow{2}{*}{ No. } & \multirow{2}{*}{ Produk } & \multicolumn{6}{|c|}{ Kadar Nutrisi (\%) Produk Pakan } \\
\hline & & Air & Protein & Lemak & Serat Kasar & BETN & Abu \\
\hline 1. & $\begin{array}{l}\text { UKKMB } \\
25 \%\end{array}$ & 27.41 & 25.06 & 11.28 & 18.32 & 21.01 & 24.33 \\
\hline 2 & $\begin{array}{l}\text { UKKMB } \\
50 \%\end{array}$ & 27.94 & 23.36 & 11.19 & 17.11 & 13.72 & 34.62 \\
\hline 3 & $\begin{array}{l}\text { UKKMB } \\
100 \%\end{array}$ & 27.54 & 22.34 & 10.87 & 15.54 & 17.22 & 34.03 \\
\hline 4. & $\begin{array}{l}\text { Jerami Non } \\
\text { Fermentasi }\end{array}$ & 12.13 & 5.87 & 2.85 & 38.19 & 32.20 & 20.89 \\
\hline 5. & $\begin{array}{c}\text { Jerami } \\
\text { Fermentasi }\end{array}$ & 10.61 & 7.87 & 3.08 & 36.90 & 27.90 & 24.25 \\
\hline 6. & $\begin{array}{c}\text { Rumput } \\
\text { gajah }\end{array}$ & 77.28 & 6.57 & 2.33 & 39.40 & 40.52 & 11.18 \\
\hline
\end{tabular}

Catatan: 1) Hasil analisis laboratorium Kimia dan Makanan Ternak Fakultas Peternakan Unhas

2) Selain air, hasil analisis dihitung berdasarkan bahan kering 
penggemukan. Demikian pula kadar serat kasar yang cukup tinggi, rata-rata $17.32 \%$ dapat menggantikan rumput gajah sebagai pakan dasar yang umum digunakan oleh mitra PKM pada penggemukan sapi di kandang.

\section{Jerami Padi Fermentasi Probiotik}

Produk jerami fermentasi dihasilkan dari proses fermentasi jerami padi menggunakan probiotik Supplement Organic Cair (SOC) selama 10-12 hari. Jerami padi sebanyak

$150 \mathrm{~kg}$ ditumpuk beberapa tumpukan setelah diperciki dengan larutan probiotik SOC yang telah diencerkan dengan perbandingan 30cc SOC dilarutkan ke dalam 45 liter air bersih. Di antara tumpukan ditaburi bekatul atau dedak yang sangat halus. Setelah $10-12$ hari jerami padi sudah terfermentasi dan siap untuk digunakan sebagai pakan sapi. Hasil analisis laboratorium memperlihatkan nilai nutrisi yang lebih baik dari pada jerami padi tanpa fermentasi (Tabel 2). Kadar protein jerami fermentasi 2\% lebih tinggi dari jerami sebelum difermentasi menjadi 7,87\%.

Pascapelatihan, telah dilakukan pembuatan jerami fermentasi probiotik sebanyak 2 kali dengan jumlah 150 $\mathrm{kg}$ per pembuatan, dimana produk ini diproduksi untuk kebutuhan pakan sapi di kandang.

\section{Pertambahan Bobot Badan Sapi}

Pemberian pakan UKKMB sebanyak 500 gr/ekor/hari dan jerami fermentasi $6 \mathrm{~kg} / \mathrm{ekor} / \mathrm{hari}$ menghasilkan pertambahan bobot badan $0.55 \mathrm{~kg} /$ hari/ekor.

\section{PENUTUP}

\section{Kesimpulan}

1. Pelatihan dalam bentuk pemaparan makalah dan praktikum telah dilaksanakan dengan sukses, diikuti sebanyak 30 orang anggota kelompok tani Sikapa dan Padaelo sebagai mitra PKM.

2. Pembuatan UKKMB dan jerami padi fermentasi telah ditindak lanjuti oleh anggota kelompok tani pascapelatihan.
3. Spesifikasi produk UKKMB dan Jerami Fermentasi memenuhi persyaratan sebagai pakan ternak sapi.

4. Pertambahan bobot badan sapi Bali mencapai $0.55 \mathrm{~kg} /$ ekor/hari.

\section{Saran}

Penambahan kolagen dalam pakan suplemen blok UKKMB sampai 100\% dapat disarankan.

\section{DAFTAR PUSTAKA}

Abustam, E. 1993. Karakteristik kualitatif karkas dan daging ternak sapi Bali dan Kerbau. Buletin Penelitian Unhas, VIII (20-23):11-21

Abustam, E. 2012. Ilmu Daging: Aspek Produksi, Kimia, Biokimia, dan Kualitas. Cet. 1. Masagena Press, Makassar

Abustam, E, M. Yusuf, M. Zain Mide, dan H. M. Ali 2012. Ipteks Bagi Masyarakat (IbM) Koperasi Peternakan Sapi Perah Manassa Kecamatan Cendana Kabupaten Enrekang. Laporan PPM DP2M Dikti, Fakultas Peternakan Universitas Hasanuddin

Abustam, E, M. Yusuf, M.I. Said, dan M. Zain Mide. 2015. IbM Showroom Sapi Bali di Kecamatan Tanete Riaja Kabupaten Barru. Laporan PPM DP2M Dikti, Fakultas Peternakan Universitas Hasanuddin

Abustam, E, M.I. Said dan M. Yusuf. 2017. Pengaruh Persentase Kolagen Dalam Pakan Suplemen Blok Dan Waktu Maturasi Pada Kualitas Daging Sapi Bali. Prosiding Seminar Nasional Peternakan 2017 Hal 432 439. Fakultas Peternakan Universitas Hasanuddin

BPS, 2013. Kabupaten barru Dalam Angka 2013. Badan Pusat Statistik Kabupaten Barru

Payne, W.J.A. and J. Hodges. 1997. Tropical Cattle: Origin, Breeds and Breeding Policies. Blackwell Science

Sastradipradja, D. 1990. Potensi internal sapi Bali sebagai salah satu sumber plasma nutfah untuk menunjang pembangunan peternakan sapi potong dan ternak kerja secara nasional. Pros. Seminar Nasional Sapi Bali. Denpasar, 20-22

September. Denpasar: Fakultas Peternakan Universitas Udayana. Hlm A-47-A54. 